\title{
KÜLÖNBÖZŐ ERDÉSZETI BEAVATKOZÁSOK HATÁSA EGY GYERTYÁNOS-TÖLGYES AVARTAKARÓJÁRA
}

\author{
Sass Vivien ${ }^{1}$, Ódor Péter ${ }^{2}$ és Bidló András ${ }^{1}$ \\ ${ }^{1}$ Soproni Egyetem, Erdömérnöki Kar, Környezet- és Földtudományi Intézet \\ 2Ökológiai Kutatóközpont, Ökológiai és Botanikai Intézet
}

\begin{abstract}
Kivonat
A Pilis Üzemmód Kísérlet keretében különböző kezelések (tarvágás, bontóvágás, hagyásfacsoport, lékvágás) avar menynyiségére és kémhatására gyakorolt hatását vizsgáltuk. A jelen publikációban ismertetett négyéves időszak alatt a kontrollállományok avarviszonyai nem változtak, ugyanakkor a kezelések az általunk vizsgált mindhárom avarváltozót (tömeg, nedvesség, kémhatás) jelentős mértékben befolyásolták. Az avartömeg a hagyásfacsoportban volt a legmagasabb, azonban ez a terület bizonyult a legszárazabbnak is. A legkevesebb avarmennyiséget a tarvágásokban mértük. A kezelések legerősebb hatással az avar kémhatására voltak: a tarvágásban és kismértékben a lékekben is megemelkedett a pH, amit a megváltozott aljnövényzet eredményezett. Eredményeink alapján megállapítható, hogy a kismértékủ bontás nem okoz változást az avarviszonyokban, a hagyásfacsoportok hatékonyan ellensúlyozzák a vágásterületek megváltozott avarviszonyait, illetve a lékek sokkal kisebb mértékben változtatják meg az avarviszonyokat, mint a vágásterületek. Ezek alapján megállapítható, hogy a finom léptékű beavatkozásokon alapuló örökerdő üzemmód kedvezőbb avarviszonyokat biztosít, mint a vágásos erdőgazdálkodás.
\end{abstract}

Kulcsszavak: Pilis Üzemmód Kísérlet, erdőkezelés, avar, lék, tarvágás

\section{THE EFFECTS OF DIFFERENT FORESTRY TREATMENTS ON LITTER CONDITIONS IN AN OAK-HORNBEAM FOREST}

\begin{abstract}
The long-term effects of different forestry treatments (clear-cutting, preparation cutting, retention tree groups, gap-cutting) on litter conditions were studied in the framework of the „Pilis Forestry Systems Experiment”. During the four-year period described in this publication, the average litter features of the closed control forest area remained unchanged, however, the treatments significantly influenced all the studied litter-variable (quantity, moisture, pH). Litter quantity was the highest in retention tree groups, although this area was the driest. The lowest quantity of litter was measured in clear-cutting. The treatments had the highest effect on the acidity/alkalinity: $\mathrm{pH}$ increased in case of clear-cuttings and a less extent gapcuttings, caused by the increased herbaceous understory cover. We can conclude that moderate partial cutting (preparation cutting) did not change the litter conditions, retention tree groups can buffer the extreme effect of clear-cuttings, and gaps only slightly modify the litter conditions compared to the clearcuts. These results show that continuous cover forestry maintain more favorable litter conditions than rotation forestry systems.
\end{abstract}

Keywords: Pilis Üzemmód Kísérlet, forest management, litter, gap 


\section{BEVEZETÉS}

Az erdőállományokban bekövetkező változások kihatnak a vele kölcsönhatásban álló más környezeti rendszerekre is. Kutatások igazolták, hogy tarvágott területen az első évtizedekben csökken az avar mennyisége, megnő a talaj hőmérséklete és nedvességtartalma (Covington 1981), átmenetileg jelentősen megnövekedik a felvehető tápanyagok mennyisége (Prescott 2002, Muscolo et al 2007), a nitrogén-ciklusban pedig szélsőséges változás áll be (Ritter 2005). Avarmanipulációs kísérletekben (Huang \& Spohn 2015) avar hiányában a talaj A-szintjében megemelkedett az összes-, a szerves és a felvehető szervetlen foszfor mennyisége, ami valószínűleg a hajszálgyökérzet szintén megemelkedett biomasszájának köszönhető. A B-szintben viszont csökkent az összes foszfor és az összes nitrogén.

Bár hazai erdeinkben régóta zajlanak avarvizsgálatok, ezek többnyire különböző fafajú, illetve eltérő termőhelyű állományokat vetettek össze (Járó 1958, Kondorné 2007), valamint az avarintercepció kutatására irányultak (Führer 1994, Gácsi 2000, Zagyvainé Kiss 2012), vagy avarmanipulációs kísérletek (Kotroczó et al 2017) voltak.

Az 2015-ben indult Pilis Üzemmód Kísérlet a vágásos üzemmód (tarvágás, bontóvágás, hagyásfacsoport a vágásterületen) és az örökerdő üzemmód (lékkialakítás) esetében előforduló beavatkozások hatását vizsgálja a termőhelyre, a felújulásra és a biodiverzitásra (Ódor et al 2020, https://www.piliskiserlet.okologia.mta. hu/). Mikroklímára és talajnedvességre vonatkozó kutatásaik megállapították, hogy a tarvágás szélsőséges léghőmérséklet és páratartalom viszonyokkal rendelkezik, a hagyásfacsoport a vágásterület napi hőingását kompenzálja, az átlagértékeket, viszont alig. Ezzel szemben a lékben és a bontásban a zárt erdei mikroklíma hőmérséklet és páratartalom viszonyok alig változnak (Kovács et al 2020). Felújulás szempontjából a lék hasonlóan kedvező viszonyokat teremt, mint a vágásterület (Tinya et al 2020), de saját vizsgálataink is igazolták, hogy az árnyéktürő fafajok visszaszoritása szükséges a tölgy érdekében, és a tölgy beavatkozások utáni kolonizációja korlátozott (von Lüpke 1998, Van Couwenberghe et al 2013).

Jelen publikációban a kezelések avarváltozókra (avartömeg, avarnedvesség, avarkémhatás) gyakorolt hatását vizsgáljuk a kezelések utáni rövid távú (4 éves) időszakban.

\section{A KÍSÉRLET BEMUTATÁSA}

A kutatási területünk a Pilisi Parkerdő Zrt. gazdálkodása alatt álló, Hosszú-hegyi közel 40 ha-os, gyertyános-tölgyes erdőrészletekben (Pilisszántó 21A, 24C, 25B) található.

Az Erdőállomány Adattár szerint a gyertyános-tölgyes klímába tartozó, többletvízhatástól független hidrológiájú, Ramann-féle barna erdőtalajú, középmély termőrétegű és vályog fizikai féleségű területet változatos lejtés jellemzi (Kovács et al 2018). Az erdészeti tájban az éves csapadék sokéves átlaga $614 \mathrm{~mm}$, az évi középhőmérséklet $9,3^{\circ} \mathrm{C}$ (Führer et al 2019). Az átlagos erdészeti szárazsági index (FAl) a községhatárban 5,8, ami szintén gyertyános-tölgyes klímára utal. A helyszíni vizsgálataink azt mutatták, hogy a részben homokkőre, részben dolomitra rakódott löszön, illetve egyéb üledéken kialakult állományban a domborzatnak és kitettségnek megfelelően a mélyben változatos talajviszonyok vannak, ugyanakkor a felszín közeli néhány deciméteres rétegben nagy különbségek nem jelentek meg (Kovács et al 2018, 1. melléklet).

A vizsgált három erdőrészletben kb. 80 százalékos elegyaránnyal a kocsánytalan tölgy (Quercus petraea) 75 éves állománya alkotja a felső szintet, amelyhez gyertyán (Carpinus betulus) (12-16\%), illetve egy-egy erdőrészletben bükk (Fagus sylvatica) (8\%) és csertölgy (Quercus cerris) (4\%) társul. A második lombszintnek domináns fafaja a gyertyán. 


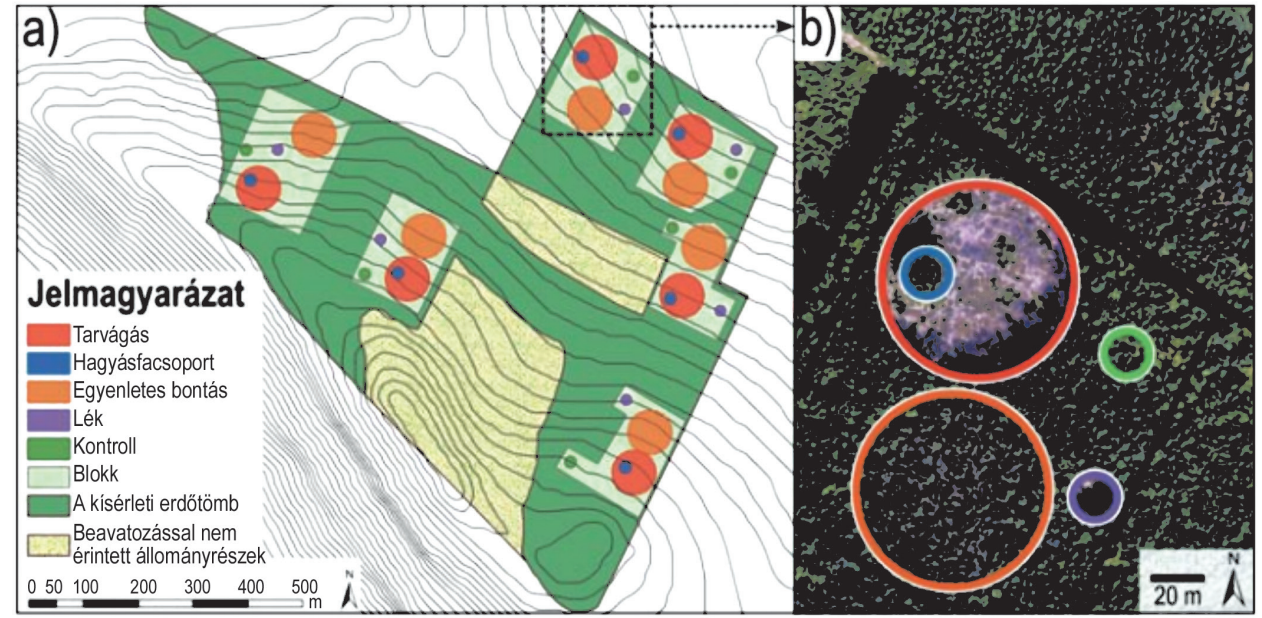

1. ábra: A blokkok és a kezelések kísérleti elhelyezése a Pilis Üzemmód Kisérlet területén Figure 1: Spatial design of blocks and treatments in the area of Pilis Forestry Systems Experiment

A kísérlet keretében négyféle kezelést hasonlítottunk össze (egyenletes bontás, lékvágás, mikrotarvágás, hagyásfacsoport), kontrollként a zárt, bontatlan állomány szolgált. A lékvágás és a hagyásfacsoport területe $300 \mathrm{~m}^{2}$ (20 m átmérőjű kör), a bontás és a mikrotarvágás területe 0,5 ha (80 m átmérőjű kör) volt. $A$ bontás esetében a felső lombkoronaszint egyharmadát, valamint a második lombkoronaszintet távolítottuk el. A kísérlet teljes blokk elrendezésben valósult meg, az öt kezelési szintet (négy kezelés és a kontroll) hat blokk területén valósítottuk meg (1. ábra). Az öt kezelés és a hat ismétlés (blokk) összesen 30 mintaterületet eredményezett.

Az erdészeti beavatkozásokat 2015 év elején, a vegetációs időszakon kívül végezték el. Az ezt megelőző évben a vizsgált változók állapotát rögzítettük még a beavatkozások előtt, vagyis a kísérlet lehetővé teszi a beavatkozás előtti és utáni állapotok összehasonlítását is (BACl: Before/After - Control//mpact elrendezés, Green 1979).

\section{ANYAG ÉS MÓDSZER}

Vizsgálatainkhoz évente kétszer gyüjtöttünk be avarmintákat: a késő tavaszi-kora nyári (T) és az őszi (O) időszakban. Mintaterületenként négy mintavételi pontból - a fö égtájak irányában, a terület középpontjától 8-10 m-re gyüjtöttük be az avart egy $30 \mathrm{~cm}$ x $30 \mathrm{~cm}$-es (9 dm²-es) területről.

A mintavételt követően laboratóriumi vizsgálatok során meghatároztuk az egyes avarminták tömegét, nedvességtartalmát, valamint a vizes kémhatását. Utóbbit a Magyar Szabvány (MSZ-08-0206/2:1978) szerinti módszer avarra módosított metodikája alapján, avar és desztillált víz 1:5 arányában mértük le. Az adott mintaterületekről vett négy alminta értékeit átlagoltuk, vagyis minden mintaterülethez egy értéket rendeltünk a vizsgált változók esetében minden időszakban. Az ismételt mintavétel elemzése során az évek (2014-2018) és az évszakok (tavasz, ősz) kombinációjából származó 10 időszakot különítettünk el.

A beavatkozásoktól mentes kontroll (zárt erdő) esetében vizsgáltuk az időszakok hatását a három változó (avartömeg, avarnedvesség, avarkémhatás) eredeti értékeire. Ezt lineáris kevert modellek alkalmazásával elemeztük (Zuur et al 2009). Ennek során az időszakokat teszteltük fix faktorként, a blokkokat random faktornak tekintettük. A modellek normális hibatag eloszlást feltételeztek, a modellek utáni hibatagok normális eloszlását kvantilis-kvantilis ábrával, a hibatagok variancia homogenitásának feltételét szórás-becsült 
érték ábrákkal ellenőriztük vizuálisan (Reiczigel et al 2007). A fix faktor hatását $F$ teszttel ellenőriztük, variancia magyarázatát „likelihood” becslésen alapuló determinisztikus koefficienssel $\left(R^{2}\right)$ fejeztük ki (Barton 2019). Szignifikáns fix faktor esetében a fix faktor szintjei közötti eltérések feltárásához Tukey-féle többszörös összehasonlítást alkalmaztunk $p=0,05$ elsőfajú hibaszint feltételezése mellett, a szintek marginális átlagai alapján (Lenth 2016).

A kezelések hatását nem a változók eredeti értékein, hanem a kontrollhoz viszonyított relatív értékeken teszteltük. Ennek során minden időszakban és minden blokkban kivontuk a négy kezelés esetében mért értékből az adott blokk kontroll területén mért értékeket (vagyis a kontroll az adott változó 0 értékének feleltethető meg). Az így kapott különbségek a kezelések egymáshoz viszonyított eltéréseit tükrözik, nem jelennek meg bennük sem az egyes időszakok, sem a blokkok abszolút különbségei. Az avartömeg, avarnedvesség és az avarkémhatás esetében a kezelések és az időszakok hatását (mint fix faktorokat) teszteltük lineáris kevert modellekkel a fentiekhez hasonló módon, a blokkokat random faktorként kezelve. Mivel itt két fix magyarázó változónk volt, azok interakcióját is figyelembe vettük a modellekben. A többszörös összehasonlításokat csak a kezelések szintjei között végeztük el, az egyes időszakok szintjein belül.

Az elemzések R 3.6.3 statisztikai környezetben történtek (R Core Team 2020), a lineáris kevert modellekhez az „nlme” (Pinheiro et al 2020), az R² értékekhez a „MuMIn” (Barton 2019), a többszörös összehasonlításokhoz az „Ismeans” (Lenth 2016) programcsomagot használtuk.

\section{EREDMÉNYEK ÉS MEGVITATÁSUK}

\section{Avartömeg}

1. táblázat: A mintavételi időszakokban gyüjtött avarminták átlagos tömege. Az oszlopok fejlécében a kezelések kódjai (T - tarvágás, L - lékvágás, $B$ - bontás, $H$ - hagyásfacsoport, $K$ - kontrol), a soroknál az időszakok kódjai találhatók. Az időszakokat évek (2014-2018) és az évszakok (T - tavasz, O ősz) kombinációi jelentik

Table 1: The mean value of the litter mass in treatments during the study periods. The codes of the treatments $(T-c l e a r-c u t, ~ L-g a p-c u t$, $B$ - pretention cut, $\mathrm{H}$ - retention tree group, $\mathrm{K}$-control) are in the column headers and the headers of rows show the codes of periods.

Periods are combinations of years (2014-2018) and seasons (T-spring, 0 - autumn)

\begin{tabular}{|c|c|c|c|c|c|c|}
\hline & \multicolumn{5}{|c|}{ Átlagos avartömeg $\left(\mathrm{g} / \mathrm{m}^{2}\right)$} \\
\hline & & $T$ & $L$ & B & $\mathrm{H}$ & $\mathrm{K}$ \\
\hline \multirow{10}{*}{ 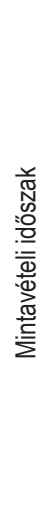 } & 2014.T & 804,51 & 844,51 & 858,19 & 902,09 & 813,76 \\
\hline & 2014.0 & 560,52 & 595,22 & 505,78 & 566,24 & 641,67 \\
\hline & 2015.T & 867,18 & 929,39 & 982,13 & 897,50 & 775,50 \\
\hline & 2015.0 & 718,71 & 670,63 & 735,16 & 1126,08 & 923,88 \\
\hline & 2016.T & 216,74 & 525,55 & 512,72 & 582,65 & 780,31 \\
\hline & 2016.0 & 156,00 & 427,83 & 879,75 & 641,50 & 853,49 \\
\hline & 2017.T & 176,75 & 511,94 & 802,51 & 962,35 & 1023,78 \\
\hline & 2017.0 & 346,20 & 777,66 & 951,70 & 777,28 & 1198,43 \\
\hline & 2018.T & 246,96 & 451,77 & 672,18 & 769,07 & 885,25 \\
\hline & 2018.0 & 97,39 & 395,16 & 474,32 & 673,19 & 871,48 \\
\hline
\end{tabular}

A kontroll mintaterületeken az avar tömege a különböző időszakokban $640-1200 \mathrm{~g} / \mathrm{m}^{2}$ között változott (1. táblázat). A kapott értékek az egyes időszakok között eltértek (kevert modell; $R^{2}=0,31 ; F_{(9 ; 45)}=3,14$; 
$p=0,0051)$, de ebben sem a tavasz-ősz, sem az évek nem mutattak trend jellegü eltérést (2. ábra). Az egyes évek közötti eltérést sokkal inkább az adott év időjárási viszonyai és a mintavétel időpontja befolyásolhatták. A vizsgálati időszak alatt jelentősebb károsodás nem jelent meg az erdőállományban, így ez nem lehetett hatással az avartömegre.

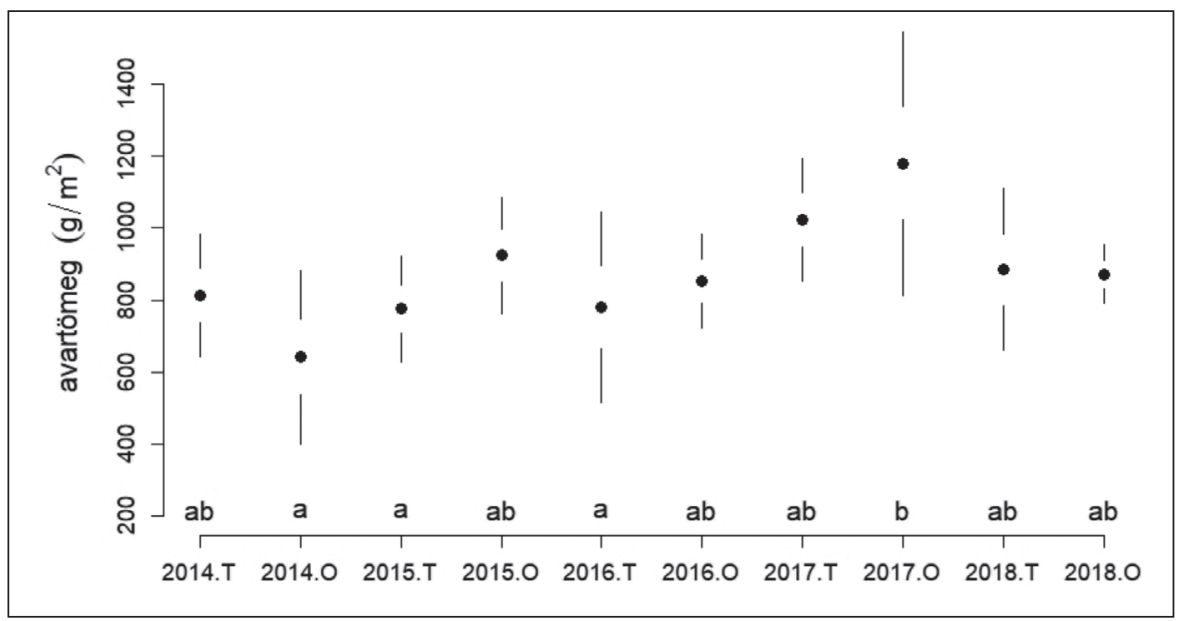

2. ábra: Az avartömeg értékei a kontroll mintaterületeken a vizsgált időszakokban. A pont az átlagot, az üres szakasz az átlag szórását (S.E.), a pálcika a szórást (S.D.) jelenti. Az időszakokat évek (2014-2018) és az évszakok (T-tavasz, O - Ősz) kombinációi jelentik. Az x tengely feletti betük a többszörös összehasonlitás során a $p=0,05$ szingifikancia szint alapján eltérő ill. azonos csoportokat kódolják Figure 2: Values of the litter mass in the control plots during the study period. The dot means the mean, the empty section means the standard error (S.E.), and the vertical line means the standard deviation (S.D.). The letters below the x-axis are the combinations of years (2014-2018) and seasons ( $T$ - spring, 0 - autumn). The letters above the $x$-axis encode the different and the same groups based on the multiple comparisons. Significance level $p=0.05$

A relatív (kontrollhoz viszonyított) avartömeg esetében a kezelés és az időszakok hatása nagyjából azonos volt (2. táblázat).

A beavatkozások elött (2014) az avarviszonyok nem különböztek a kezelésekre kijelölt mintaterületek között (3. ábra). A kezelés utáni első év (2015) őszén már megfigyelhető volt, hogy a relatív avartömeg a hagyásfacsoportban a legnagyobb, és ez a tendencia többé-kevésbé a teljes vizsgálati időszakban megmaradt. Ez alapvetően 0 körüli érték (hasonló, mint a kontrollban), míg a többi kezelésre negatív, vagyis a kontrollnál kevesebb avartömeg volt a jellemző. A 2016-os évtől kezdve megfigyelhető az avar alacsonyabb mennyisége a tarvágásban, ami innentől az összes vizsgálati időszakban alacsonyabb, mint a hagyásfacsoportban, az eltérés az idővel nőtt. A lék és a bontás értékei a tarvágás és a hagyásfacsoport közötti köztes értékeket vettek fel, egymástól alapvetően a legtöbb időszakban nem különböztek. Ennek ellenére a lék átlaga alacsonyabb, gyakrabban mutatott átfedést a tarvágással, a bontásé magasabb, gyakrabban alkotott közös csoportot a hagyásfacsoporttal. 
2. táblázat: $A$ vizsgált változók esetében a lineáris kevert modellek fix faktorainak determinisztikus koefficiense $\left(R^{2}\right)$, szabadsági foka $(d F)$, F-értéke (F) és szignifikancia szintje (p). A hibatag szabadsági foka minden modell esetében 194

Table 2: The table shows the coefficient of determination $\left(R^{2}\right)$, the degree of freedome $(d f)$, the $F$ value $(F)$, and the significance level $(p)$ of the fix factors within the linear models. For all models, the degree of freedom of the residual error is 194

\begin{tabular}{|l|c|c|c|}
\hline & dF & F & p \\
\hline Relatív avartömeg; $\mathrm{R}^{2}=0,467$ & 3 & & $<0,0001$ \\
\hline Kezelés & 9 & 14,62 & $<0,0001$ \\
\hline Idöszak & 27 & 1,66 & 0,0273 \\
\hline Interakció & & & \\
\hline Relatív avarnedvesség; $\mathrm{R}^{2}=0,476$ & 3 & 23,14 & $<0,0001$ \\
\hline Kezelés & 9 & 7,85 & $<0,0001$ \\
\hline Időszak & 27 & 3,50 & $<0,0001$ \\
\hline Interakció & & & $<0,0001$ \\
\hline Relatív avarkémhatás $(\mathrm{pH}) ; \mathrm{R}^{2}=0,642$ & 3 & 70,49 & $<0,0001$ \\
\hline Kezelés & 27 & 8,34 & $<0,0001$ \\
\hline Időszak & 9 & 6,17 & \\
\hline Interakció & & & \\
\hline
\end{tabular}

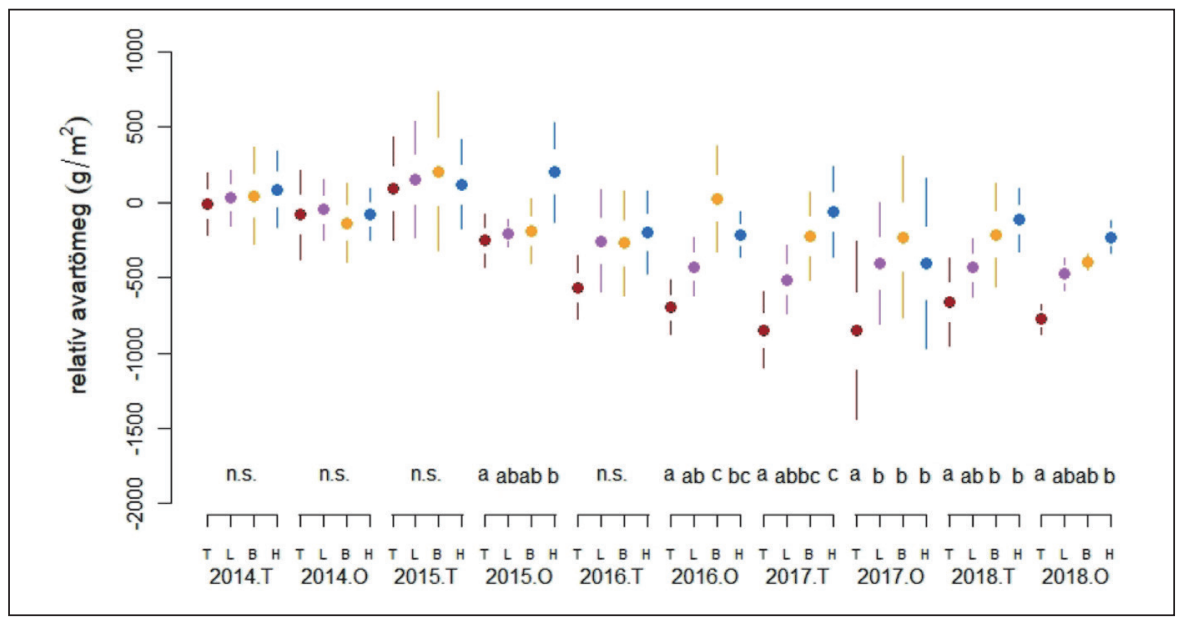

3. ábra: A kontrollhoz viszonyított (relativ) avartömeg értéke a különböző kezelésekben és időszakokban. A pont az átlagot, az üres szakasz az átlag szórását (S.E.), a pálcika a szórást (S.D.) jelenti. Színkódok: bordó - tarvágás, lila - lékvágás, sárga - bontás, kék - hagyásfacsoport. Az x tengely alatti első sorban a kezelések kódjai ( $T$ - tarvágás, $L$ - lékvágás, $B$ - bontás, $H$ - hagyásfacsoport), a második sorban az időszakok kódjai találhatók. Az időszakokat évek (2014-2018) és az évszakok (T - tavasz, O - ősz) kombinációi jelentik. Az x tengely feletti betük a többszörös összehasonlitás alapján a $p=0,05$ szignifikancia szint alapján eltérő ill. azonos csoportokat kódolják a kezelések között, egy adott időszakon belül

Figure 3: Value of the (relative) litter mass compared to the control in the different treatments and periods. The dot means the mean, the empty section means the standard error (S.E.), and the vertical line means the standard deviation (S.D.). Color codes: burgungy clear-cut, purple - gap-cut, yellow - preparation cut, blue - retention tree group. The codes of the treatments ( $T$ - clear-cut, $L$ - gap-cut, $B$ - preparation cut, $\mathrm{H}$ - retention tree group) are in the first row under the $\mathrm{x}$-axes, and the second row show the codes of periods.

Periods are combinations of years (2014-2018) and seasons (T-spring, 0 - autumn). The letters above the $x$-axis encode the different and the same groups in the multiple comparison in a same period. Significance level $p=0.05$ 


\section{Avarnedvesség}

3. táblázat: A mintavételi időszakokban gyüjtött avarminták átlagos nedvességtartalma kezelésenként. Az oszlopok fejlécében a kezelések kódjai ( $T$ - tarvágás, $L$ - lékvágás, $B$ - bontás, $H$ - hagyásfacsoport, $K$ - kontrol), a soroknál az időszakok kódjai találhatók.

Az időszakokat évek (2014-2018) és az évszakok (T-tavasz, O - ősz) kombinációi jelentik

3. table: Mean value of the litter moisture in treatments during the study periods. The codes of the treatments ( $T$ - clear-cut, $L-g a p-c u t$, $B$ - pretention cut, $\mathrm{H}$ - retention tree group, $\mathrm{K}$ - control) are in the column headers and the headers of rows show the codes of periods.

Periods are combinations of years (2014-2018) and seasons (T - spring, 0 - autumn)

\begin{tabular}{|l|c|c|c|c|c|}
\hline \multirow{2}{*}{} & \multicolumn{5}{|c|}{ Átlagos nedvességtartalom (\%) } \\
\cline { 2 - 6 } & $\mathbf{T}$ & L & B & H & K \\
\hline 2014.T & 4,50 & 4,09 & 4,49 & 4,67 & 3,45 \\
\hline $\mathbf{2 0 1 4 . 0}$ & 57,30 & 55,59 & 57,26 & 57,78 & 56,39 \\
\hline $\mathbf{2 0 1 5 . T}$ & 53,74 & 53,78 & 54,25 & 52,69 & 51,99 \\
\hline $\mathbf{2 0 1 5 . 0}$ & 56,16 & 60,98 & 48,08 & 36,56 & 38,70 \\
\hline $\mathbf{2 0 1 6 . T}$ & 30,27 & 37,80 & 33,76 & 21,01 & 33,72 \\
\hline $\mathbf{2 0 1 6 . 0}$ & 58,10 & 59,29 & 55,31 & 52,39 & 58,01 \\
\hline $\mathbf{2 0 1 7 . T}$ & 45,14 & 59,91 & 48,31 & 27,18 & 40,30 \\
\hline $\mathbf{2 0 1 7 . 0}$ & 69,76 & 61,55 & 61,23 & 59,05 & 60,82 \\
\hline $\mathbf{2 0 1 8 . T}$ & 43,28 & 38,37 & 40,87 & 25,14 & 34,95 \\
\hline $\mathbf{2 0 1 8 . 0}$ & 77,04 & 71,39 & 68,67 & 67,63 & 67,59 \\
\hline
\end{tabular}

A mintaterületen az avarnedvességet elsősorban a mintavétel előtt időjárás (csapadék és hőmérséklet viszonyok) határozza meg. A területen csak az utóbbi 3 évben állnak rendelkezésre csapadék adatok, így ezeket nem tudtuk bevonni a vizsgálatba, jelen vizsgálatnak nem volt célja az időjárás hatásának elemzése az avartakaró mennyiségére, elsősorban azt vizsgáltuk milyen eltérés tapasztalható a kontroll területhez képest. A kontroll területen az időszakok között jelentős eltérés mutatkozott (kevert modell, $R^{2}=0,93 ; F_{(9,45)}=137,96$; p<0,001; 4. ábra). 2014 tavaszán a kontrollban az avarnedvesség igen alacsony volt (3,5\%), négy időszakban 30-40\% közötti, négy időszakban 50-60\% közötti, míg egy időszakban 67\%-os értéket vett fel (3. táblázat). 2016-2018 között az őszi időszakok magasabb avarnedvességet mutattak, mint a tavaszi időszakok, 2015ben ezt nem lehetett megfigyelni.

Az időjárás hatása miatt, az avarnedvességi viszonyokat elsősorban a kontrollal összehasonlítva érdemes értékelni. A relatív avarnedvesség esetében a kezelések hatása erősebbnek bizonyult, mint az időszakoké (2. táblázat). A relatív avarnedvesség a beavatkozás előtt, illetve a kezelés utáni tavaszon nem tért el a kezelések között, a kontrollhoz hasonló (0 körüli) értéket vett fel (5. ábra). A 2015-ös év őszén a lékben és a tarvágásban volt a legmagasabb, a hagyásfacsoportban a legalacsonyabb, a bontás köztes értékeket vett fel. A 2016-2018 közötti időszakban ősszel nem tapasztaltunk az avarnedvességben eltérést a kezelések között, tavasszal viszont igen. Ezt magyarázhatja az is, hogy az őszi időszakokban általánosan magasabb volt a talaj nedvességtartalma (4. ábra), ezért a kezelések közötti eltérések kisebbek voltak, mint a tavaszi, szárazabb időszakokban. Minden ilyen esetben, amikor szignifikáns eltérést tapasztaltunk a kezelések között, a hagyásfacsoportban szignifikánsan alacsonyabb volt az avarnedvesség, mint a többi kezelésben. A másik három kezelés 2016 és 2018 tavaszán nem különült el. A lék két időszakban is (2015 ősz, 2017 tavasz) szignifikánsan magasabb talajnedvesség értéket mutatott, mint a többi kezelés. 


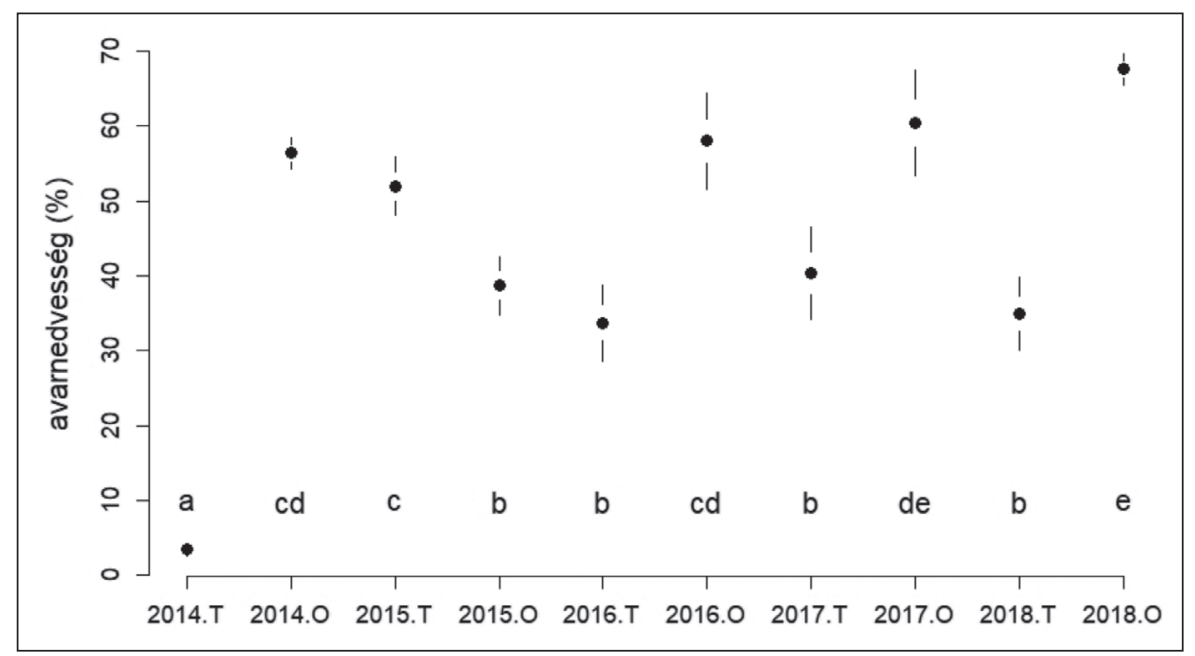

4. ábra: Az avarnedvesség értékei a kontroll mintaterületeken a vizsgált időszakokban. A pont az átlagot, az üres szakasz az átlag szórását (S.E.), a pálcika a szórást (S.D.) jelenti. Az időszakokat évek (2014-2018) és az évszakok (T- tavasz, O - ősz) kombinációi jelentik. Az x tengely feletti betük a többszörös összehasonlitás alapján a $p=0,05$ szingifikancia szint alapján eltérő ill. azonos csoportokat kódolják

Figure 4: Values of the litter moisture in the control plots in the period studied. The dot means the mean, the empty section means the standard error (S.E.), and the vertical line means the standard deviation (S.D.). The letters below the x-axis are the combinations of years (2014-2018) and seasons ( $T$ - spring, 0 - autumn). The letters above the $x$-axis encode the different and the same groups based on the multiple comparisons. Significance level $p=0.05$

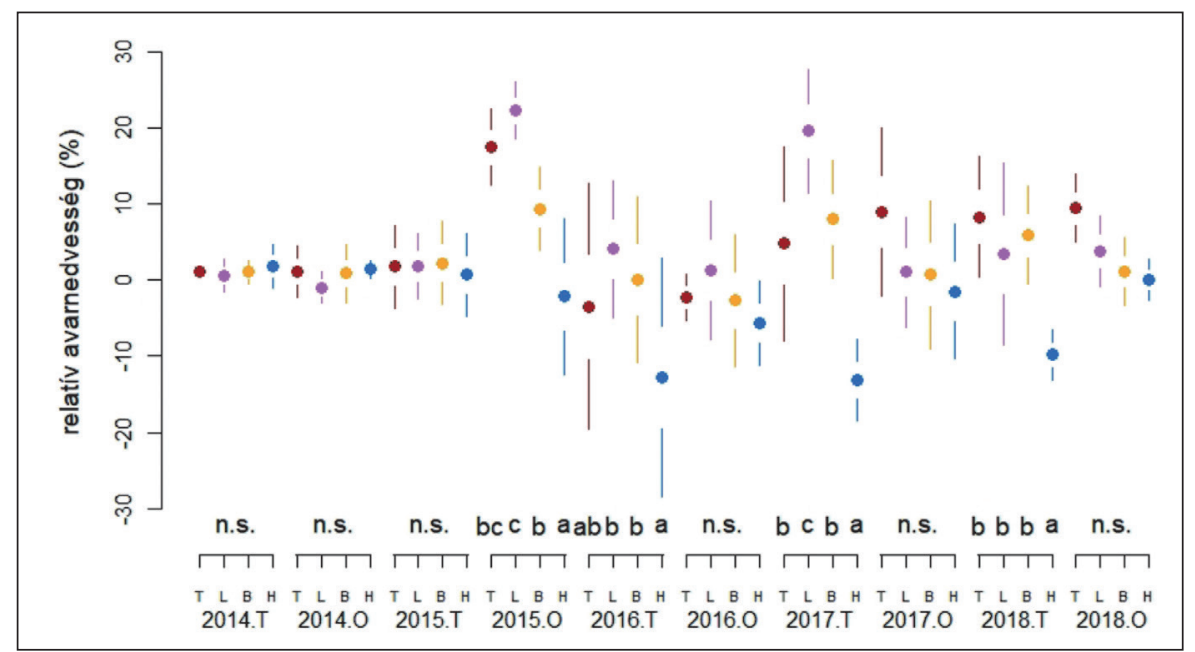

5. ábra: A kontrollhoz viszonyított (relativ) avarnedvesség értéke a különböző kezelésekben és időszakokban. A pont az átlagot, az üres szakasz az átlag szórását (S.E.), a pálcika a szórást (S.D.) jelenti. Színkódok: bordó - tarvágás, lila - lékvágás, sárga - bontás, kék - hagyásfacsoport. Az x tengely alatti első sorban a kezelések kódjai ( $T$ - tarvágás, $L$ - lékvágás, $B$ - bontás, $H$ - hagyásfacsoport), a második sorban az időszakok kódjai találhatók. Az időszakokat évek (2014-2018) és az évszakok (T - tavasz, O ősz) kombinációi

jelentik. Az x tengely feletti betűk a többszörös összehasonlitás alapján a $p=0,05$ szignifikancia szint alapján eltérő ill. azonos csoportokat kódolják a kezelések között, egy adott időszakon belül

Figure 5: Value of the (relative) litter moisture compared to the control in the different treatments and periods. The dot means the mean, the empty section means the standard error (S.E.), and the vertical line means the standard deviation (S.D.). Color codes: burgungy clear-cut, purple - gap-cut, yellow - preparation cut, blue - retention tree group. The codes of the treatments ( $T$-clear-cut, $L-g a p-c u t$,

$\mathrm{B}$ - preparation cut, $\mathrm{H}$ - retention tree group) are in the first row under the $\mathrm{x}$-axes, and the second row show the codes of periods. Periods are combinations of years (2014-2018) and seasons ( $T$ - spring, $O$ - autumn). The letters above the $x$-axis encode the different and the same groups in the multiple comparison in a same period. Significance level $p=0.05$ 


\section{Avarkémhatás $\left(\mathrm{pH}_{\mathrm{H}_{2} \mathrm{O}}\right)$}

Az avar vizes kémhatása a kontrol mintaterületeken pH 4,5 és 5,3 között változott (4. táblázat), az egyes időszakok szignifikánsan eltértek (kevert modell, $R^{2}=0,69, F_{(9,45)}=19,03, p<0,0001$ ). A kémhatás 2016 őszén és 2018 tavaszán mutatott a többi időszakhoz képest magasabb pH értékeket (6. ábra).

4. táblázat: A mintavételi időszakokban gyüjtött avarminták átlagos kémhatása kezelésenként. Az oszlopok fejlécében a kezelések kódjai ( $T$ - tarvágás, $L$ - lékvágás, $B$ - bontás, $H$ - hagyásfacsoport, $K$ - kontrol), a soroknál az időszakok kódjai találhatók. Az időszakokat évek (2014-2018) és az évszakok (T - tavasz, O - ősz) kombinációi jelentik

Table 4: Mean $\mathrm{pH}$ value of the litter in treatments during the study periods. The codes of the treatments ( $T$ - clear-cut, $L-g a p$-cut, $B$ - pretention cut, $\mathrm{H}$ - retention tree group, $\mathrm{K}$ - control) are in the column headers and the headers of rows show the codes of periods. Periods are combinations of years (2014-2018) and seasons (T-spring, O - autumn)

\begin{tabular}{|c|c|c|c|c|c|}
\hline & \multicolumn{5}{|c|}{ Átlagos $\mathrm{pH}_{\mathrm{H} 20}$} \\
\hline & $T$ & L & B & H & K \\
\hline 2014.T & 4,97 & 4,88 & 4,85 & 4,98 & 4,88 \\
\hline 2014.0 & 4,42 & 4,41 & 4,33 & 4,47 & 4,47 \\
\hline 2015.T & 4,58 & 4,49 & 4,41 & 4,44 & 4,46 \\
\hline 2015.0 & 5,37 & 5,21 & 4,59 & 4,53 & 4,56 \\
\hline 2016.T & 5,38 & 5,11 & 4,90 & 4,88 & 4,92 \\
\hline 2016.0 & 5,71 & 5,51 & 5,34 & 5,12 & 5,28 \\
\hline 2017.T & 5,39 & 4,97 & 4,80 & 4,59 & 4,61 \\
\hline 2017.0 & 5,73 & 4,52 & 4,51 & 4,40 & 4,48 \\
\hline 2018.T & 6,65 & 5,42 & 5,35 & 5,11 & 5,29 \\
\hline 2018.0 & 5,20 & 4,62 & 4,49 & 4,48 & 4,60 \\
\hline
\end{tabular}

Az avar kémhatás relatív értékének esetében összességében a kezelések hatása meghaladta az időszakok hatását (2. táblázat). A beavatkozás előtt, illetve a beavatkozás utáni tavaszon a kezelések nem különböztek egymástól, ezután minden időszakban szignifikáns eltérés jelentkezett a kezelések között (7. ábra). Alapvetően a tarvágásokban szignifikánsan magasabb pH értékeket mértünk, mint a többi kezelésben, ez a beavatkozás utáni 3. és 4. évtől (2017-2018) egységesen jelentkezett. A hagyásfacsoport mutatta a legalacsonyabb $\mathrm{pH}$ értéket. $\mathrm{A}$ bontás esetében a $\mathrm{pH}$ a hagyásfacsoporténál többnyire magasabb volt, de attól nem tért el statisztikailag. A lék értékei a tarvágás és a bontás között helyezkedtek el, a 2015-2016 időszakban inkább a tarvágással, 2017-2018-ban a bontással és a hagyásfacsoporttal alkottak közös statisztikai csoportot. 


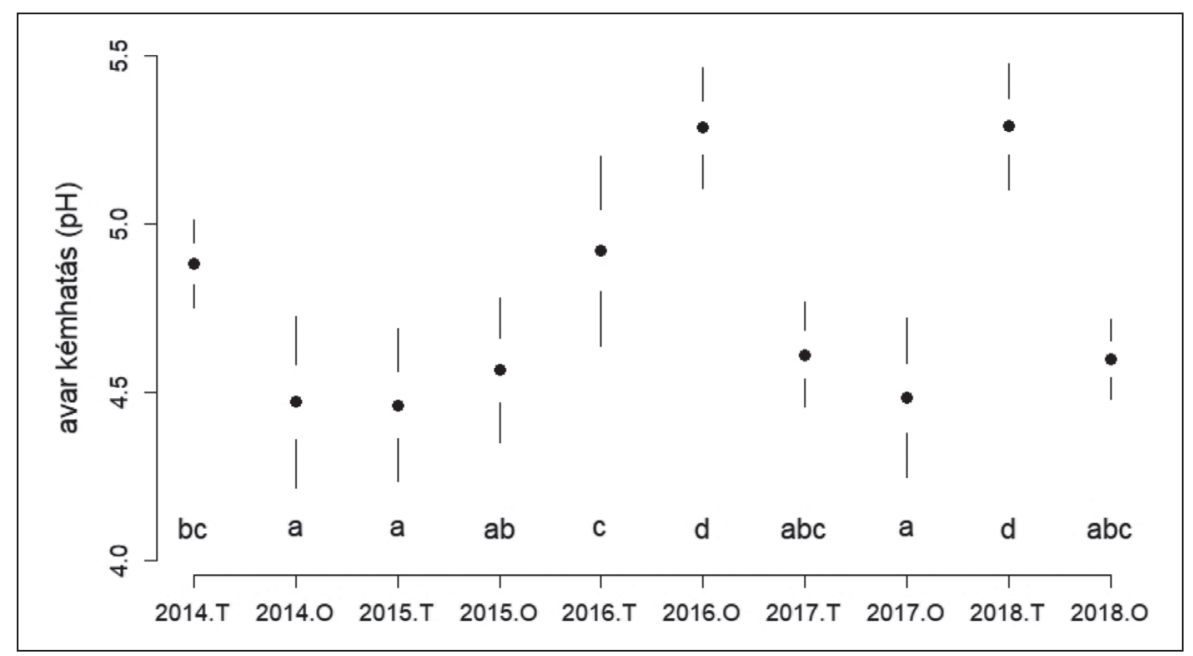

6. ábra: Az avarkémhatás (pH) értékei a kontroll mintaterületeken a vizsgált időszakokban. A pont az átlagot, az üres szakasz az átlag szórását

(S.E.), a pálcika a szórást (S.D.) jelenti. Az időszakokat évek (2014-2018) és az évszakok (T - tavasz, O - ősz) kombinációi jelentik.

Az x tengely feletti betük a többszörös összehasonlitás alapján a $p=0,05$ szingifikancia szint alapján eltérő ill. azonos csoportokat kódolják Figure 6: The $\mathrm{pH}$ values of the leaf litter in the control plots in the period studied. The dot means the mean, the empty section means the standard error (S.E.), and the vertical line means the standard deviation (S.D.). The letters below the $x$-axis are the combinations of years (2014-2018) and seasons ( $T$ - spring, 0 - autumn). The letters above the $x$-axis encode the different and the same groups based on the multiple comparisons. Significance level $p=0.05$

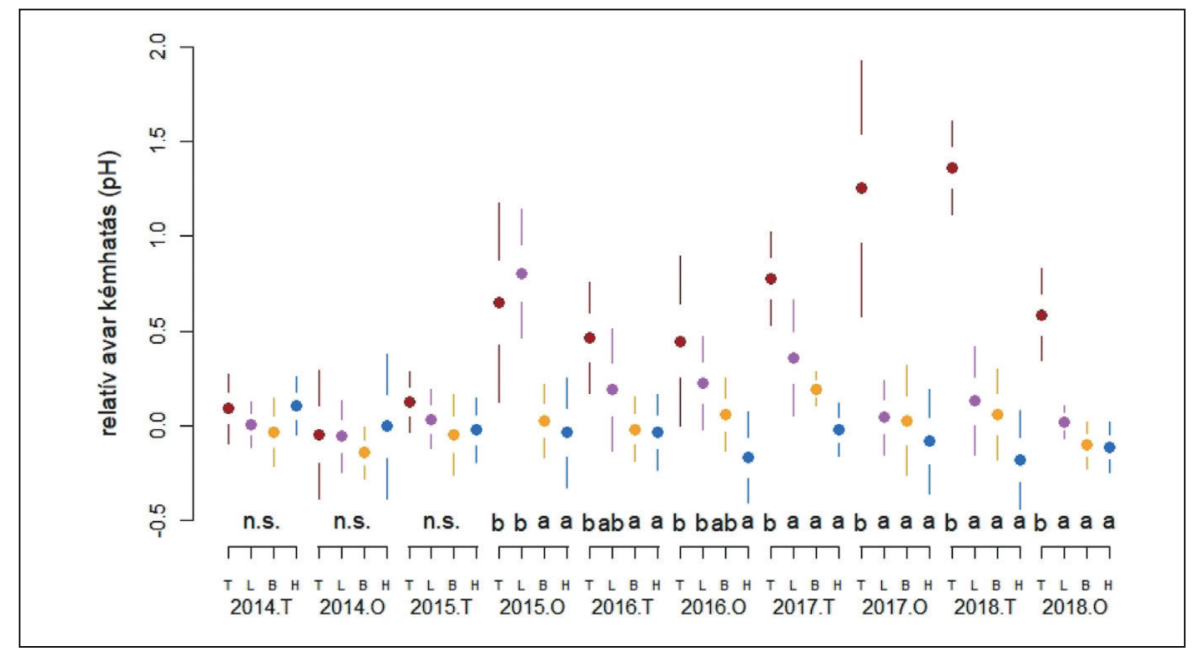

7. ábra: A kontrollhoz viszonyitott (relatív) avarkémhatás $(\mathrm{pH})$ értéke a különböző kezelésekben és időszakokban. A pont az átlagot, az üres szakasz az átlag szórását (S.E.), a pálcika a szórást (S.D.) jelenti. Színkódok: bordó - tarvágás, lila - lékvágás, sárga - bontás, kék - hagyásfacsoport. Az x tengely alatti első sorban a kezelések kódjai ( $T$ - tarvágás, $L$ - lékvágás, $B$ - bontás, $H$ - hagyásfacsoport), a második sorban az időszakok kódjai találhatók. Az időszakokat évek (2014-2018) és az évszakok (T- tavasz, O ősz) kombinációi

jelentik. Az x tengely feletti betük a többszörös összehasonlitás alapján a p =0,05 szignifikancia szint alapján eltérő ill. azonos csoportokat kódolják a kezelések között, egy adott időszakon belül

Figure 7: Value of the (relative) litter $\mathrm{pH}$ compared to the control in the different treatments and periods. The dot means the mean, the empty section means the standard error (S.E.), and the vertical line means the standard deviation (S.D.). Color codes: burgungy - clear-

cut, purple - gap-cut, yellow - preparation cut, blue - retention tree group. The codes of the treatments (T-clear-cut, $L$ - gap-cut,

$\mathrm{B}$ - preparation cut, $\mathrm{H}$ - retention tree group) are in the first row under the $\mathrm{x}$-axes, and the second row show the codes of periods.

Periods are combinations of years (2014-2018) and seasons (T-spring, 0 - autumn). The letters above the $x$-axis encode the different and the same groups in the multiple comparison in a same period. Significance level $p=0.05$ 


\section{KÖVETKEZTETÉSEK}

A kontroll mintaterületeken a vizsgálati időszak alatt egyetlen trendszerű jelenséget lehetett megfigyelni, hogy az avarnedvesség ősszel magasabb volt, mint tavasszal, de ezt pusztán az okozta, hogy az őszi mintavételek csapadékosabb időszakokra estek. Az avartömegben trend jellegű változásokat nem lehetett megfigyelni. Az avar kémhatása 2016 őszén és 2018 tavaszán neutrálisabb volt a többi időszaknál, azonban ez nehezen értelmezhető, sem az avarprodukció, sem az avarnedvesség értékekkel ez nincs összefüggésben. Összességében elmondható, hogy a kontroll állományok avarviszonyai, várakozásainknak megfelelően, nem változtak.

Ezzel szemben a kezelések mindhárom avarváltozót jelentős mértékben befolyásolták, a legerősebb kezeléshatást az avarkémhatás mutatta.

A begyüjtött minták alapján, a 2015-ös beavatkozás óta eltelt időszakban avarmennyiség tekintetében a kezelések között egyre nőtt a különbség (8. ábra). Az avartömeg a hagyásfacsoport, bontás, lék és tarvágás sorrendben csökkent a kezelések között, ami teljesen összefügg a keletkező lombavar mennyiségével.

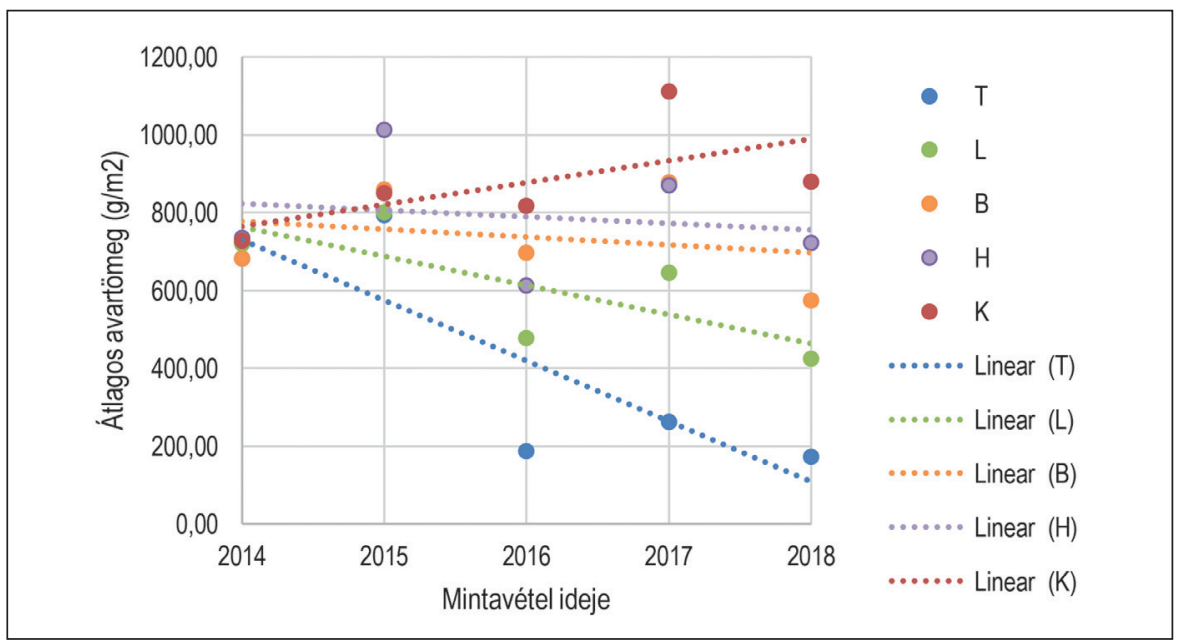

8. ábra: Az éves avarmennyiség átlagértéke a különböző kezelésekben. A színkódok az egyes kezeléseket jelölik ( $T$ - tarvágás, $L$ - lékvágás, $B$ - bontás, $H$ - hagyásfacsoport, $K$ - kontroll)

Figure 8: The mean value of the annual litter mass in the different treatments. The colors encode the treatments ( $T$ - clear-cut, $L$ - gap-cut, $B$ - pretention cut, $\mathrm{H}$ - retention tree group, $\mathrm{K}$ - control).

A hagyásfacsoport e tekintetben hasonló faállománnyal rendelkezik, mint a kontroll. Ugyanakkor a hagyásfacsoportban számolnunk kell az avar lebomlás gátlásával is, mert ezen a területen az avar, illetve a talaj felső szintje előbb kiszárad, mint a többi területen. Ennek oka kettős - egyrészt a megmaradó faállomány gyökere jelentős mennyiségű nedvességet vesz fel a talajból, másrészt az állomány talaja jobban ki van téve az oldalról érkező napsugárzás hatásának. Bontás esetében a fák kb. harmada hiányzik, a lékben csak a lékek széléről származik lombavar produkció, míg a tarvágásban a lombavar mennyisége minimális. A tarvágásban és a lékben az avar jóval nagyobb hányadát teszi ki a lágyszárú vegetációból származó avar, azonban ez a faállomány lombavarjának csökkenését nem tudja kompenzálni.

Avarnedvesség tekintetében a lékben tapasztaltuk a legmagasabb értékeket (bár ez nem mindig különült el a tarvágástól és a bontástól), viszont egyértelműen alacsonyabb volt a hagyásfacsoportban. Ezt a jelenséget mindig csak a tavaszi, vízlimitált időszakban mutattuk ki, az őszi, nedvesebb időszakokban nem jelentkezett. Ezek az eredmények nagyon hasonló trendet mutattak, mint a talajnedvesség (Kovács et al 2020). Mivel 
lombkorona nélkül csökken az avarmennyiség is, így a talajba bejutó csapadékmennyiség megnő (Zagyvainé Kiss et al 2015). A lékben és a tarvágásban a faállomány hiánya tehát egyrészt lecsökkenti az intercepciót, másrészt a másik jelentős hatás, hogy a fák transpirációjának talajnedvesség csökkentő hatása nem jelentkezik. Ez a nedvességnövelő hatás erősebben érvényesül a lékben, mint a tarvágásban, hiszen azt kiegyenlítettebb mikroklíma (kisebb hőingás, magasabb légnedvesség) jellemzi az állomány pufferoló hatása miatt, így a párolgás itt kevésbé intenzív. A hagyásfacsoportban egyrészt érvényesül a faállomány nedvességcsökkentő hatása (intercepció, transpiráció), másrészt mivel egy szélsőséges mikroklímájú vágásterület veszi körül, az evaporáció is jelentős. Természetesen a faállománynak ezek a hatásai elsősorban a száraz időszakokban érvényesülnek.

Az avarkémhatás neutrálisabb jellege elsősorban a tarvágásban jelenik meg, amely az itt nagy tömegben megjelenő lágyszárú növényzettel magyarázható, ezek uralkodó fajai a beavatkozás utáni 3. és 4. évben a siskanádtippan (Calamagrostis epigeios), a magas aranyvessző (Solidago gigantea) és a szeder (Rubus fruticosus agg.) (Tinya et al 2019). Ez a lágyszárú növényzet a lebomlása során sokkal neutrálisabb avarviszonyokat eredményez, mint a többi kezelésben meghatározó tölgylevél avar. Ez a neutrális avarkémhatás a lékben kevésbé jelentkezik, aminek az egyik magyarázata, hogy itt kevésbé történt meg a vágástéri növényzet elburjánzása az aljnövényzetben. Bár itt is megnőtt a növényzeti borítás, ennek mértéke kisebb volt, valamint elsősorban erdei fény-flexibilis növények alkották (Tinya et al 2019). A másik hatás, hogy itt a lékszéli fák jelentős tölgylevél avar produkciót biztosítanak, ami a pH-t csökkenti. Azonban ennek ellenére a lékben is valamivel neutrálisabb viszonyok vannak, mint a bontásban illetve a hagyásfacsoportban.

Eredményeink alapján az erdőgazdálkodási gyakorlat számára is hasznosítható megállapítások tehetők. A faállomány kb. egyharmadát eltávolító bontás a kontrollhoz képest alig változtatta meg az avarviszonyokat, vagyis a záródás és a körlapösszeg kismértékű csökkentése (a vágásos üzemmód idős korosztályához képest) nem okoz eltérő avarviszonyokat.

A beavatkozások közül a tarvágás mind az avarmennyiség, mind a kémhatás tekintetében drasztikus változásokat okoz: az avartömeg lecsökken, a vágástéri növényzet hatására neutrálisabbá válik. Ezek a hatások a lékben kevésbé érvényesülnek a fák közelsége, és az aljnövényzet kisebb mértékű változása miatt. A lékek a tölgyesek időszakosan vízlimitált termőhelyi viszonyai között növelik az avar és a talaj nedvességtartalmát. Vagyis az örökerdő üzemmódra jellemző kisterületű felújitások sokkal kevésbé változtatják meg az avarviszonyokat, mint a vágásos üzemmód vágásterületei.

A vágásos üzemmód hatásainak (Keenan \& Kimmins 1993) ellensúlyozása céljából, a vágásterületeken visszahagyott hagyásfacsoportok az avarviszonyok tekintetében részben ellátják kiegyenlítő (pufferoló) funkciójukat. Az avarmennyiség a kontrollhoz hasonló, kémhatás viszonyai szintén megegyeznek. Viszont avarnedvesség tekintetében a hagyásfacsoportok szárazabb, kedvezőtlenebb viszonyokat biztosítanak a vágásterület negatív hatása miatt.

Összességében elmondható, hogy az avarviszonyok tekintetében a vizsgált területen az örökerdő üzemmód kis területü lékjei, illetve alacsonyabb záródású állományai kedvezőbbek, mint a vágásos üzemmód nagy területű felújításai. A hagyásfacsoportok visszahagyásának nagy jelentősége van az avarviszonyok fenntartása szempontjából a vágásos üzemmód keretén belül, ugyanakkor ezen részeken a talaj gyorsabb kiszáradása miatt, a felújulás gátolt lehet. Vizsgálataink csak a beavatkozás utáni első évekre terjedtek ki, a kezelések avartakaróra gyakorolt hosszabb távú hatásának vizsgálatához további mérések szükségesek.

\section{KÖSZÖNETNYILVÁNÍTÁS}

A kutatás az Ökológiai Kutatóközpont, a Soproni Egyetem és a Pilis Parkerdő Zrt. kooperációjában valósult meg. 
Jelen publikáció az „EFOP-3.6.1-16-2016-00018 - A felsőoktatási rendszer K+F+I szerepvállalásának növelése intelligens szakosodás által Sopronban és Szombathelyen" címü projekt támogatásával valósult meg. A kutatást az NKFIA (OTKA) K128441 számú projektje és a «Társadalmi jóllét ökológiai alapjai” program (MTA KEP) támogatta.

\section{FELHASZNÁLT IRODALOM}

Bartoń K. 2019: MuMIn: Multi-Model Inference. R package version 1.43.15. https://CRAN.R-project.org/package=MuMln.

Covington W.W. 1981: Changes in forest floor organic matter and nutrient content following clear cutting in Nothern Hardwoods. Ecology 62(1):41-48.

Führer E. 1994: Csapadékmérések bükkös, kocsánytalan tölgyes és lucfenyves ökoszisztémában. Erdészeti Kutatások 84: 11-35.

Führer E., Heil B., Heilig D., Jagodics A. \& Kovács G. 2019: Termőhelyi viszonyok. In: Führer E. (ed): Magyarország erdészeti tájai. III. Dunántúli-középhegység erdészeti tájcsoport, Nemzeti Földügyi Központ, Budapest, 126-137.

Gácsi Zs. 2000: A talajvízszint észlelés, mint hagyományos, és a vízforgalmi modellezés, mint új módszer alföldi erdeink vízháztartásának vizsgálatában. Doktori (Ph.D) értekezés, Nyugat-Magyarországi Egyetem, Sopron.

Green, R.H. 1979: Sampling desing and statistical methods for environmental biologist. John Wiley and Sons Inc., New York.

Huang, W. \& Spohn, M. 2015: Effects of long-term litter manipulation on soil carbon, nitrogen and phosphorus in temperate deciduous forest. Soil Biology \& Biochemistry 83:12-18.

Járó Z. 1958: Alommennyiségek a magyar erdők egyes típusaiban. Erdészettudományi Közlemények 1958. 151-162.

Keenan R.J. \& Kimmins J.P. 1993: The ecological effects of clear-cutting. Environmental Reviews 1: 121-144.

Kondorné Sz. M. 2007: Fafaj-összehasonlító kísérletek értékelése. Doktori (Ph.D) értekezés, Nyugat-Magyarországi Egyetem, Sopron.

Kotroczó Zs., Biró B., Kocsis T., Veres Zs., Tóth A. \& Fekete I. 2017: Hosszú távú szerves anyag manipuláció hatása a talaj biológiai aktivitására. Talajvédelem 73-83.

Kovács B., Tinya F., Guba E., Németh,C., Sass V., Bidló A. \& Ódor P. 2018: The short-term effects of experimental forestry treatments on site conditions in an oak-hornbeam forest. Forests 9: 406.

Kovács B., Tinya F., Németh Cs. \& Ódor P. 2020: Unfolding the effects of different forestry treatments on microclimate in oak forests: results of a 4-year experiment. Ecological Applications 30(2): e02043.

Lenth R.W. 2016: Least-Squares Means: The R Package Ismeans. Journal of Statistical Software 69(1): 1-33.

Muscolo A., Sidari M. \& Mercurio R. 2007: Influence of gap size on organic matter decomposition, microbial biomass and nutrient cycle in Calabrian pine (Pinus laricio, Poiret) stands. Forest Ecology and Management 242: 412-418.

MSZ-08-0206/2:1978: A talaj egyes kémiai tulajdonságainak vizsgálata. Laboratóriumi vizsgálatok. (pH-érték, szódában kifejezett fenolftalein lúgosság, vízben oldható összes só, hidrolitos ( $\mathrm{y}_{1}$-érték) és kicserélődési aciditás ( $\mathrm{y}_{2}$-érték)

Ódor P., Tinya F., Kovács B., Aszalós R., Bidló A., Boros G. et al. 2020: Különböző erdészeti beavatkozások termőhelyre, biodiverzitásra, és felújulásra gyakorolt hatása gyertyános tölgyesekben. Beszámoló egy 5 éve indult erdőökológiai kísérlet eredményeiröl. Erdészeti Lapok 155(1):8-12.

Pinheiro J., Bates D., DebRoy S., Sarkar D. \& R Core Team 2020: nlme: Linear and Nonlinear Mixed Effects Models_. R package version 3.1-144, <URL: https://CRAN.R-project.org/package=nlme>.

Prescott C.E. 2002: The influence of the forest canopy on nutrient cycling. Tree Physiology 22: 1193-1200.

R Core Team 2020: R: A language and environment for statistical computing. R Foundation for Statistical Computing, Vienna, Austria. URL https://www.R-project.org/.

Reiczigel J., Harnos A. \& Solymosi N. 2007: Biostatisztika nem statisztikusoknak. Pars Kft., Nagykovácsi.

Ritter E. 2005: Litter decomposition and nitrogen mineralization in newly formed gaps in a Danish beech (Fagus sylvatica) forest. Soil Biology \& Biochemistry 37:1237-1247. 
Snyder K.E., \& Harter R.D. 1987: Forest floor dynamics in even-aged northern hardwood stands. Soil Science Society of America Journal 51:1381-1383.

Tinya F., Kovács B., Aszalós R., Tóth B., Csépányi P., Németh Cs. \& Ódor P. 2020: Initial regeneration success of tree species after different forestry treatments in a sessile oak-hornbeam forest. Forest Ecology and Management 459: 117810.

Tinya F., Kovács B., Prättälä A., Farkas P., Aszalós R. \& Ódor P. 2019: Initial understory response to experimental silvicultural treatments in a temperate oak-dominated forest. European Journal of Forest Research 138: 65-77.

Van Couwenberghe R., Gegout J.C., Lacombe E., Collet C. 2013: Light and competition gradients fail to explain the coexistence of shade-tolerant Fagus sylvatica and shade-intermediate Quercus petraea seedlings. Annals of Botany 112: $1421-1430$.

von Lüpke B. 1988: Silvicultural methods of oak regeneration with special respect to shade tolerant mixed species. Forest Ecology and Management 106 (1): 19-26.

Zagyvainé Kiss K. A. 2012: Az avarintercepció vizsgálata a Soproni-hegységben. Doktori (Ph.D) értekezés, Nyugatmagyarországi Egyetem, Sopron.

Zagyvainé Kiss K. A., Vastag V., Gribovszki Z. \& Kalicz P. 2015: Soil moisture in sessile oak forest gaps. In EGU General Assembly Conference Abstracts (Vol. 17).

Zuur A.F., leno E.N., Walker N.J., Saveliev A.A. \& Smith G. 2009: Mixed effects models and extension in ecology with R. Springer, New York.

Érkezett: 2020. július 02.

Közlésre elfogadva: 2020. október 29. 